\title{
19: 6344184-6330581
}

National Cancer Institute

\section{Source}

National Cancer Institute. 19:6344184-6330581. NCI Thesaurus. Code C42439.

Physical location of GTF2F1_Gene 